Agro-Science Journal of Tropical Agriculture, Food, Environment and Extension Volume 15 Number 1 January, 2016 pp. 6-10

ISSN 1119-7455

\title{
VARIATIONS IN SEED TRAITS OF CASTOR (Ricinus communis) ACCESSIONS COLLECTED FROM ENUGU STATE, NIGERIA
}

\author{
Udoh*, O.E., Abu, N.E., Ugwueze, C. and Ebeifenadi, U.C. \\ Department of Plant Science \& Biotechnology, University of Nigeria, Nsukka \\ *Corresponding author's email: obioraudoh@yahoo.com
}

\begin{abstract}
Four accessions (Accessions 1, 2, 3 and 4) of castor (Ricinus communis) were grown in Botanical Garden of the University of Nigeria, Nsukka in the derived savanna of southeastern Nigeria for two cropping seasons (2013 and 2014) in a randomized complete block design. The seeds harvested from them were subjected to chemical analysis. A soxhlet extraction was used for the extraction of the oil, using hexane as solvent. The oil was recovered by simple distillation of the solvent. The residual oil obtained was investigated for physicochemical parameters and fatty acid composition. The results showed free fatty acid compositions of linoleic acid (0.5\%), stearic acid (1.3\%) and palmitic acid (1.5\%). The results of oleic, linolenic and ricinoleic acids were also reported. The physicochemical analysis showed that castor seed and oil had saponification value of $182.9 \mathrm{mg} / \mathrm{g}$, moisture content of $4.4 \%$, acid value of $3.085 \mathrm{mg} / \mathrm{g}$, viscosity of $110.41 \mathrm{cP}, \mathrm{pH}$ of 6.11 , iodine value of $8.46 \mathrm{mg} / \mathrm{g}$, specific gravity of 0.962 and refractive index of $1.477^{\circ} \mathrm{C}$. The proximate analysis showed that moisture content of castor seeds varied from 9.02 to $9.66 \%$ while crude oil varied from 22.9 to 27 g. The results obtained were discussed in relation to the use of castor seeds in the preparation of local food condiment and the suitability of the oil quality in diverse industrial applications.
\end{abstract}

Key words: castor plant, fatty acid, physicochemical, iodine value, derived savannah

\section{INTRODUCTION}

The castor bean plant belongs to the spurge family Euphorbiaceae. Castor bean, the single member of the African genus Ricinus, presents a wide variation regarding vegetative traits such as leaf and stem colors, number and size of leaf lobes and the presence of wax covering the stem (Savy, 2005). Castor bean is cultivated for the seeds which yield vicious, pale yellow non-volatile and nondrying oil. The oil has been used only for industrial and medicinal purposes (Ogunniyi, 2006). It is widely used as a laxative-cathartic agent, particularly in cases of certain radiological examinations which require prompt and thorough evacuation of the small intestine (Stubiger et al., 2003).

Castor oil is one of the few naturally occurring glycerides with high purity since the fatty acid portion is nearly $90 \%$ of ricinoleic (Akpan et al., 2006). The oil is not only a naturally occurring resource; it is also inexpensive and environmentally friendly. Relative to other vegetable oils, it has a good shelf life. Hot pressing via hydraulic presses extracts between 75 and $85 \%$ of the oil contained in castor beans, while the remaining press cake has about $12 \%$ oil content (Mensah and Ochran, 2005). Ogunniyi (2006) mottling on testa (Mensah and Ochran, 2005). Lit et al. (2008) described the seeds as shiny brown found out that mechanical pressing will remove about $45 \%$ of the oil and the remaining oil in the cake can be recovered only by solvent extraction. Many publications reported that ricinoleic acid is a major component in castor oil; 89.2-94.9\% (Conceicaoet al., 2007), about 70-90\% (Fogalia et al., 2000), 87-90\% (Puthli et al., 2006) 89\% (Ogunniyi, 2006) and 90.2\% (Conceicao, 2007). Ramos et al., (1984) had surveyed 36 castor bean varieties in Brazil for oil and fatty acid composition. A large variability of seed oil percentage was observed, ranging from 39.6-59.5\%.

Castor oil has been used for coating fabrics and other protective coverings, in the manufacture of high-grade lubricants, transparent typewriter and printing inks, in textile dyeing, in the leather preservation and in the production of 'Rilson', a polyamide nylon-type fiber (Puthli et al., 2006).

The spiny seed pod or capsule is composed of three sections or carpels which split at maturity. Each carpel contains a single seed and as the carpel dries and spilt open, the seed is often ejected with considerable force (Meinder and Jones, 1995). Castor seeds are nearly flattened and oval but differ in size and color. The seeds may be white, black, brown or several colour occurring as very attractive seeds with darker streaks or spots and resemble a blotted tick. A number of colors are usually found 
in castor seeds. The most striking ones are red, white and gray. Others are faint chocolate, deep chocolate and purple. The sizes of castor seed have been reported to vary from a few millimeters long to about $20 \mathrm{~mm}$ in the giant species (Weiss, 2000). The seed weight varies. For instance, seeds found in Nigeria and Kenya has been reported to weigh 69.3 and $59.2 \mathrm{~g}$, respectively (Li et al., 2008).

The typical fatty acid composition of castor oil shows ricinoleic to be within the range of 89.595\%, Linoleic acid 4.2-4.5\%, Palmitic and Stearic acid 1-2\% (Salunkhe and Desai, 1986; Mensah and Ochran, 2005). According to Indian standard, good quality castor oil should have an acid value less than 3-4, saponification value 175-185, hydroxyl value $160-170$, iodine value $82-90$, refractive index $1.473-1.477$ and specific gravity 0.945-0.965 (Weiss, 2000).

The fatty acid composition of Malaysian castor seed oil reveals that ricinoleic acid comprises over $84 \%$ of the total fatty acid composition (Jumat et al., 2010). Other fatty acids present were linoleic $(7.3 \%)$, oleic $(5.5 \%)$, palmitic $(1.3 \%)$, stearic $(1.2 \%)$ and linolenic $(0.5 \%)$. The unsaturated fatty acids content was $97.5 \%$ of the total fatty acids composition. Gupta et al. (2006) reported that the ricinoleic acid content from India and Brazil castor bean oils were $94.0 \%$ and $90.2 \%$; which were higher than Malaysian sample.

Although several works have been carried on castor in other parts of the world, such is virtually unavailable for castor under Nigerian environmental conditions. Hence the objective of this work was to determine the physicochemical and oil properties of the different accessions. The research will provide information on the performance of castor in derived savannah AgroEcology (Enugu State) since such information virtually unavailable.

\section{MATERIALS AND METHODS}

Four accessions of $R$. communis were collected from four different locations namely Nsukka, Ibagwa-Aka, Aninri and Enugu-Ezike (6.84-6.98 $\mathrm{N}, 7.38-7.44^{\circ}$ E) in Enugu State, Nigeria. The accessions were collected from these areas in order to evaluate castor in Enugu State. The experimental plot measured $390 \mathrm{~m}^{2}$ and the experiment was laid randomized complete block design (RCBD) with three replications. Each block measuring $3 \mathrm{~m}$ by 4 $\mathrm{m}$ was subdivided into four plots with $0.5 \mathrm{~m}$ spacing between plots. A total of nine seeds of each accession were sown in each block at planting depth of 7-8 $\mathrm{cm}$ in the soil. The different genotypes were randomly assigned to each of the four plots. Randomization was repeated for each block. Standard cultural practices were applied to all plots. The seeds were harvested after 120 days when capsules color changed from green to brown. To determine the average seed size, 100 clean seeds were randomly picked from the harvested seeds after planting and their linear dimensions namely; length (L), width (W) and thickness (T) were measured using micrometer-caliper with an accuracy of $0.05 \mathrm{~mm}$. The surface area, arithmetic mean, geometric mean volume and sphericity were determined using the procedure outline by Mohsenin (1986). Accessions one and four were spiny in texture and large in seed size while accession two was small in size and accession four was medium in size. The seeds harvested from the field were cleaned and sorted before grinding into a paste for oil analysis. The oil analysis was done at Springboard Laboratory, Awka in 2014. A soxhlet extractor was used for solvent extraction of the oil and the color of the castor oil upon extraction is pale yellow. The solvent used was hexane and it was repeated several times, at the end of the extraction, the resulting mixture called miscella containing the oil was heated to recover the oil. The residual oil was collected and used for analysis. The $\mathrm{pH}$, moisture content, specific gravity, viscosity, ash content and saponification were determined according to AOAC (1997). Fatty acid composition of the oil was determined by modified acid-catalysed esterification and transesterification of free fatty acids using Method Ce 1-62 of AOCS (1997). The crude protein value was determined using the kjeldahl method. The fibre content was determined using the method of AOAC (1997). Parameters such as phytate, tannin and lectin were determined for each of the four randomly selected accessions. The potassium content was determined by the flame photometry method while phosphorus content was determined using the ascorbic acid method. The seed volume and the surface area were calculated using the method described by Jain and Bal. (1997). The data collected were analyzed using SPSS. Statistically significant differences were detected using LSD at $\mathrm{P}=0.05$ level of significance.

\section{RESULTS AND DISCUSSION}

Table 1 shows the axial dimensions and other parameters of the seeds of different accessions. The weight of 100 seed varied from 16.24-70.72 g. A1 (Accession 1) had the highest 100 seed weight of $56.07 \mathrm{~g}$. The sizes of castor seed have been reported to vary from 10 millimeters long to about $20 \mathrm{~mm}$ in the giant species (Weiss, 2000). The seed varies greatly in size, from a few millimeters to about $250 \mathrm{~mm}$ long in giant types and from 5 to 16 $\mathrm{mm}$ in breadth. The 100 seed weight may vary from $10-100 \mathrm{~g}$, averaging about $30 \mathrm{~g}$ in dwarfs and the mean weight of castor seeds has been reported to vary from 10-100 g; for instance, seeds found in Nigeria and Kenya have been reported to weigh $69.3 \mathrm{~g}$ and $59.2 \mathrm{~g}$ per seeds respectively (Salunkhe and Desai, 1986; Li et al., 2008). The length varied from 8.94-16.80 mm. A1 had the highest length 
value $(16.8 \mathrm{~mm})$. The range of width varied from 6.1-12.6 mm. The A3 have the highest width value of $12.6 \mathrm{~mm}$. The arithmetic mean of all the accessions ranged from 6.99 to 12.1 while the geometric mean ranged from 6.44 to 11.41 . The arithmetic mean of A3 is the highest with the value of 12.1 while A2 had the lowest arithmetic mean of 6.99. The geometric mean of A3 had the highest mean of 11.41. A3 had the highest surface area of $344.86 \mathrm{~mm}^{2}$. It ranged from $100.79 \mathrm{~mm}^{2}$ to 344.86 $\mathrm{mm}^{2}$. A3 had the highest volume of $843.94 \mathrm{~mm}^{2}$. Generally, the mean surface area and volume were high for the large-seeded accessions when compared to the small seeded accessions. The mean sphericity ranged from 0.58 to 0.69 . These characteristics are necessary for the design of equipment and machines for the transportation, sorting, cleaning, handling, drying and storage of the seeds of these various castor genotypes.

The result of fatty acid composition of the seed oil showed that ricinoleic acid comprised $84 \%$ of the total fatty acid composition (Table 2). Other fatty acids present were linolenic acid $(0.5 \%)$, stearic acid (1.3\%), palmitic acid (1.5\%), dihydrostearic acid (1.5\%), oleic acid (3.5\%) and linoleic acid $(7.5 \%)$. The unsaturated fatty acids content was $97.6 \%$ while the unsaturated fatty acids content was $97.6 \%$. The ricinoleic acid content from Nigerian accessions agrees with those in Malaysia $(84.2 \%)$ but differs from those obtained in India (94.0\%) and Brazil (90.2\%) (Jumat et al., 2010). Gupta et al. (2006) reported that the high content of ricinoleic acid of castor accessions might be due to the difference in climatic conditions. Similarity was observed in the unsaturated fatty acid content which is 97.5, 98.3, 97.6 and $97.6 \%$ for the Malaysia, Brazil, India and Nigeria genotypes used in this work, respectively. The reason for this similarity may be due to the report that samples from Nigeria are more unsaturated due to the content of polyunsaturated fatty acids (PUFA). However, in most cases the castor bean oil consists mainly of 12- hydroxy-9octadecaenoic acid; ricinoleic acid. Castor bean oil is suitable for industrial application due to the presence of hydroxyl groups (Ogunniyi, 2006). The presence of the hydroxyl group allows chemical derivation of the oil or modifies the properties of castor oil relative to vegetable oils which do not have the hydroxyl group. The hydroxyl group in castor oil can be acetylated or alkoxylated by using dehydration process to increase the unsaturation of the oil compound to provide the semi-drying castor oil. Its presence adds the extra stability to the oil thereby preventing the formation of hydroperoxides (Akpan et al., 2006).

Table 3 shows the result of physicochemical characteristics of castor oil. The oil shows high iodine value of $84.6 \mathrm{mg} / \mathrm{g}$. This is due to its high content of unsaturated fatty acid. The iodine value in this work compares well with Malaysia accessions (Jumat et al., 2010). The oil could be used extensively as lubricants and hydraulic brake fluids. The saponification value of $182.9 \mathrm{mg} / \mathrm{g}$ reported in this work was almost in the range reported by Ogunniyi (2006) which was 177-182 $\mathrm{mg} / \mathrm{g}$. The high saponification value of the oil implies that it consists primarily of high molecular weight fatty acid glycerides. Castor oil obtained from cold pressing has low acid value and has higher saponification value compared to the solvent-extracted oil (Ogunniyi, 2006). Aldo et al. (2012) reported that solvent-extracted oil was high in acid value $(10 \mathrm{mg} / \mathrm{g})$ compared to the value from the present study which was $3.085 \mathrm{mg} / \mathrm{g}$. The difference in acid value can be attributed to the quality of the oil and factors such as immature seeds and poor storage conditions. The acid value also compared favorably with that obtained for crude Jatropha oil (3.38) and Africa oil bean seed (3.25) (Esther et al., 2008; Aldo et al., 2012).

Table 1: The axial dimensions and other parameters of the seeds of different accessions

\begin{tabular}{|c|c|c|c|c|c|c|c|c|c|}
\hline Accession & $\begin{array}{l}100 \text { seed } \\
\text { weight }\end{array}$ & $\begin{array}{l}\text { Length } \pm \\
\text { S.E. }(\mathrm{mm})\end{array}$ & $\begin{array}{l}\text { Width } \pm \\
\text { S.E. }(\mathrm{mm})\end{array}$ & $\begin{array}{l}\text { Thickness } \\
\text { (mm) }\end{array}$ & $\begin{array}{l}\text { Arithmetic } \\
\text { mean }(\mathrm{mm})\end{array}$ & $\begin{array}{l}\text { Geometric } \\
\text { mean }(\mathrm{mm})\end{array}$ & $\begin{array}{c}\text { Surface } \\
\text { Area }\left(\mathrm{mm}^{2}\right)\end{array}$ & Volume & Sphericity \\
\hline A1 & $56.07 \pm 6.8$ & $16.80 \pm 0.02$ & $10.02 \pm 0.2$ & $6.1 \pm 0.05$ & $11.03 \pm 0.58$ & $10.15 \pm 0.02$ & 272.12 & 584.73 & 0.60 \\
\hline $\mathrm{A} 2$ & $17.74 \pm 1.7$ & $10.70 \pm 0.02$ & $6.92 \pm 0.05$ & $4.1 \pm 0.002$ & $6.97 \pm 0.01$ & $6.44 \pm 0.01$ & 109.69 & 145.83 & 0.60 \\
\hline A3 & $70.72 \pm 15.3$ & $16.6 \pm 0.01$ & $12.6 \pm 0.01$ & $7.1 \pm 0.005$ & $12.1 \pm 0.67$ & $11.44 \pm 0.67$ & 344.86 & 843.94 & 0.69 \\
\hline A4 & $25.34 \pm 2.5$ & $11.06 \pm 0.01$ & $7.3 \pm 0.01$ & $4 \pm 0.003$ & $6.99 \pm 0.01$ & $6.39 \pm 0.01$ & 107.15 & 142.00 & 0.58 \\
\hline
\end{tabular}

Table 2: Free fatty acid composition of castor seed oil of the Nigeria accessions

\begin{tabular}{lc}
\hline Fatty Acid & Value (\%) \\
\hline Linoleic & 0.5 \\
Stearic & 1.3 \\
Palmitic & 1.5 \\
Dihydrostearic & 1.5 \\
Oleic & 3.5 \\
Linolenic & 7.5 \\
Ricinoleic & 84.2 \\
Saturated Fatty Acid & 2.4 \\
Unsaturated Fatty Acid & 97.6 \\
\hline
\end{tabular}

Table 3: Physicochemical characteristics of castor seed oil

\begin{tabular}{lc}
\hline Parameters & Value \\
\hline Saponification & 182.9 \\
Moisture Content & 4.4 \\
Acid value & 3.085 \\
Viscosity & 110.41 \\
$\mathrm{pH}$ & 6.11 \\
Iodine Value & 84.6 \\
Specific gravity & 0.962 \\
Refractive Index & 1.477 \\
\hline
\end{tabular}


Table 4: Proximate, mineral and antinutrient composition of the castor seed accessions in parts of Enugu State

\begin{tabular}{lccccccccccccccc}
\hline Accessions & \multicolumn{4}{c}{ Proximate composition } & \multicolumn{1}{c}{ Mineral composition } & \multicolumn{4}{c}{ Antinutrient composition } \\
\hline & M & TA & CO & CF & CP & TC & Mg & Ca & P & K & Oxalate & Tanin & Phytate & Lectin \\
A1 & 9.50 & 8.0 & 25.50 & 26.40 & 19.26 & 35.10 & 0.696 & 0.52 & 0.31 & 10.81 & 5.22 & 8.04 & 0.1 & 0.14 \\
A2 & 9.66 & 7.0 & 27.00 & 2.79 & 26.27 & 27.28 & 0.528 & 0.52 & 0.64 & 12.13 & 6.12 & 12.91 & 0.12 & 0.18 \\
A3 & 9.02 & 6.5 & 26.15 & 2.82 & 15.76 & 39.75 & 0.768 & 0.68 & 0.72 & 11.38 & 4.9 & 16.75 & 0.16 & 0.11 \\
A4 & 9.26 & 6.0 & 22.90 & 2.50 & 21.89 & 37.45 & 0.552 & 0.48 & 0.31 & 11.76 & 6.25 & 17.21 & 0.11 & 0.22
\end{tabular}

$\mathrm{M}=$ Moisture, $\mathrm{TA}=$ Total ash, $\mathrm{CO}=$ Crude oil $($ Fat $), \mathrm{CF}=$ Crude fibre, $\mathrm{CP}=$ Crude Protein, $\mathrm{TC}=$ Total carbohydrate $\mathrm{Mg}=\mathrm{Magnesium}, \mathrm{Ca}=$ Calicum, $\mathrm{P}=$ Phosphorus, $\mathrm{K}=$ Potassium

Physically, castor oil is a viscous, pale yellow, clear liquid at room temperature $\left(27^{\circ} \mathrm{C}\right)$ and showed no solid fat content at $0^{\circ} \mathrm{C}$. The oil is high in viscosity although this is unusual for a natural vegetable oil. The $\mathrm{pH}$ of the sample (6.11) is an indicative of the presence of a reasonable quantity of free fatty acid in the oil, which is a good indicator of the advantageous utilization of the oil in soap making. The moisture content of the crude oil was 4.4. Low moisture content could be an indication of good shelf life characteristics (Abitogun et al., 2009). The specific gravity value reported in this study is in line with Mensah and Ochran (2005) and Akpan and Mohammed (2006).

The proximate composition of the castor seeds analyzed showed a marked variation in the six parameters. The moisture content varied from 9.02 to $9.66 \%$. A2 had the highest moisture content $(9.66 \%)$. The ash ranged from 6 to $8 \mathrm{~g}$. A1 has the highest ash value. The crude oil ranged from 22.9 to $27 \mathrm{~g}$. A2 had the highest oil value of $27 \mathrm{~g}$. Fibre values differed from 2.5 to $26.4 \mathrm{~g}$. Protein content ranged from 15.67 to $26.27 \mathrm{~kJ}$. Carbohydrate varied from 27.28 to 39.75 . The magnesium content varied from $0.528 \mathrm{mg} / \mathrm{dl}$. Calcium varied from 0.48 to $0.68 \mathrm{mg} / \mathrm{dl}$. Phosphorous differed from 0.31 to $0.72 \mathrm{mg} / \mathrm{dl}$ and potassium from 10.81 to $12.13 \mathrm{mg} / \mathrm{dl}$.

The oxalate ranged from 4.90 to $6.25 \mathrm{mg} / \mathrm{l}$. Tannin varied from 8.04 to $17.21 \mathrm{mg} / \mathrm{l}$. Phytate ranged from 0.10 to $0.16 \mathrm{mg} / \mathrm{l}$. Lectin differed from 0.11 to $0.18 \mathrm{mg} / \mathrm{ml}$. The crude fiber was observed to be generally low because the seeds were dehulled except for accession one. This shows that castor seed could be used as animal feed. Akande $e t$ al. (2012) also reported that lower fiber content will influence the utilization of other nutrients by the animals when castor seeds are used in feed formulation. The crude oil content was observed to range from 22.9 to $27.0 \%$. This was low compared to the crude oil content of castor seed reported by earlier researchers (Adel et al., 2011; Britannica, 2012). The fibre content influence the utilization of other nutrient by the animals and it is very imperative to dehull castor seed before applied to animal feed particularly in the mono gastric feeding system (Akande et al., 2012). Higher oil content associated is advantageous in oil based industries and seed yield. Analysis of the mineral content showed a higher percentage of potassium. The potassium content of the seeds ranged from 10.81 to $12.13 \%$. This shows that castor seed could be a good source of potassium in diet when well fermented to minimize ricin poisoning.

The anti-nutritional factors analyzed indicated that tannin factor was high among all the antinutritional factors (Table 4). It was highest in accession 5. Lectin is a high toxic chemical component which can cause death by producing activities of agglutination when even in a very low concentration. Weiss (2000) states that a dose of $0.0035 \mathrm{mg}$ may kill a man and even small particles in open sores and in the eyes may prove fatal. The anti-nutritional factors have been reported to be responsible for the improper utilization of other nutrients present in the seeds.

\section{CONCLUSION}

The results of this study have indicated that several varieties of castor seeds found in Enugu State have different physical and chemical properties. The results of the chemical analyses have shown that castor seeds contain high nutrients with potentials to meet the nutritional requirements of farm animals if they are given proper treatment. Since seeds contain high nutrients with high potassium content, the use of the seeds as food condiment can be justified. However, one important limiting factor in the use of castor as a complementary nutrient is the presence of the poisonous ricin content of the seed. Therefore, it is advisable that the seeds should be well fermented and properly treated before they can be used either as food condiment or feed for animals.

\section{REFERENCES}

Abitogun, A.S., Alademeyin, O.J. and Oloye, D.A. (2009). Extraction and Characterization of Castor Seed Oil. The Internet Journal of Nutrition and Wellness 8 (2), 1937-8297

Akande, T.O., Odunsi, A.A., Olabode, O.S. and Ojediran, T.K. (2012). Physical and nutrient characterization of raw and processed castor (Ricinus communis L) seeds in Nigeria. World Journal of Agricultural Sciences 8 (1), 89-95

Akpan, U.G., Jimoh, A. and Mohammed, A.D. (2006). Extraction, Characterization and Modification of castor seed oil. Leonardo Journal of Science 8: 4352

AOAC. (1997). Official methods of analysis (2 ${ }^{\text {nd }}$ ed.), Washington, D.C press. p.56 
Conceicao, M.M., Candeia, R.A., Silva, F.C., Bezerra, A.F., Fernandes V.J. and Souza, A.G. (2007). Thermoanalytical characterization of castor oil biodiesel. Renewable and Sustainable Energy Reviews 11, 964-975

Duke, J.A. (1998). Ricinus communis from Purdue University New Crop Resource online Program. http://www.hort.purdue.edu/newcrop/duke_energy/ Ricinus communis. html. Accessed on 16/5/2013

Foglia, T.A., Jones, K.C. and Sonnet, P.E. (2000). Selectivity of Lipases: Isolation of fatty acids from castor, corinander and meadow foam oils. European Journal of lipid Science Technology 102 (10), 612617

Gepts, P. (2004). Crop domestication as a long-term selection experiment. Journal of Plant Science. 3, 11-15.

Gupta, S.S., Hilditch, T. and Riley, J.P. (2006). The fatty Acids and Glycerides of castor oil. Journal of the Science of Food and Agriculture. 2 (6), 245-251

Jumat, S., Dina, A.M.N., Nazrizawati, A.T., Mohd Firdaus, M.Y. and Noraishah, A. (2010). Fatty Acid Composition and Physicochemical properties of Malaysian Castor Bean Ricinus communis L. Seed Oil. Sains Malaysiana 39(5), 761-764

Li, F.J., Wang, C.L., Wang, C.F., Chen, Z.Q., Chen, M.H. and Gao, L.F. (2008). Fatty acid composition of the castor bean seed of nine castor bean hybrids. China Oils Fats 33, 62-64

Meinders, H.C. and Jones, M.D. (1995). Pollen shedding and dispersal in the castor plant Ricinus communis L. Journal of Agronomy. 4, 206-209
Mensah, B. and Ochran, R. (2005). Physiochemical characteristics of castor oil from local wild castor plant in Ghana. Ghana Journal of Science 45, 41-44

Mohsenin, N. N. (1986). Physical Properties of Plant and Animal Materials. Gordon and Breach Science Publications, New York. p. 891

Ogunniyi, D. S. (2006). Castor Oil: A Vital industrial raw material. Bioresource Technology 97, 10861091

Puthli, M.S., Rathod, V.K. and Pandit, A.B. (2006). Enzymatic Hydrolysis of Castor Oil: Process Intensification Studies. Biochemical Engineering Journal 2, 1-11

Ramos, L.C.D., Tango, J.S., Savi, A. and Leal, N.R. (1984). Variablity for Oil and Fatty Acid Composition in castor bean varieties. Journal of the American Oil Chemists' Society. 61: 1841-1843

Stubiger, G., Pittenauer, E. and Allmaier, G. (2003). Characterization of castor oil by On-line and offline Non-aqueous Reverse-phase High-performance Liquid Chromatography-Mass Spectrometry (APCI and UV/MALIDI). Phytochemical Analysis 14, 337346

Weiss, E. A. (2000). Castor, Sesame and Safflower. Leonard Hill London. p. 901 